\title{
Performance in and Preference for Anatomy Amongst Para-Clinical and Clinical Students of Vet- erinary Medicine, At the University of Ibadan
}

\section{Awosanya, Emmanuel1; Olopade, Funmilayo2; Sowemimo, Damilola ${ }^{1}$; and James O. Olopade ${ }^{1}$}

${ }^{1}$ Department of Veterinary Anatomy, University of Ibadan, Nigeria

2 Department of Anatomy, University of Ibadan, Nigeria

With 3 tables \& 1 Appendix

Received Feb. 2021, accepted for publication August

\section{Abstract}

Anatomists, clinicians and public health experts agree that knowledge of anatomy is vital to safe and efficient clinical practice, and of relevance to meat inspection. With little known about the impact of teaching anatomy to veterinary students; we conducted a pilot study to determine the performance and preference of veterinary students about learning anatomy and their predictors. We administered structured questionnaire to 39 paraclinical and 87 clinical students of the Faculty of Veterinary Medicine, University of Ibadan, Nigeria. Descriptive statistics and test of significance between categorical variables was done using Fisher's exact test at 5\% significant level. The study revealed that most students $(73.0 \%)$ passed all anatomy courses at first sitting and that $87.3 \%$ preferred Veterinary Gross-Anatomy to either Micro-anatomy or Embryology. The use of combinations of lecture notes, text-books and audiovisuals was highly significant J. Vet. Anat.
$(\mathrm{OR}=20.2 ; 95 \% \mathrm{Cl} 2.4-967.1)$ to passing anatomy at first sitting. In the logistic regression, variables such as students' impression about learning anatomy $(\mathrm{OR}=5.3 ; 95 \% \mathrm{Cl} 1.4-$ 19.5); impression about the pattern of teaching Microanatomy $(\mathrm{OR}=0.1$; $95 \% \mathrm{Cl} 0.02-0.4$ ) and adequacy of continuous assessment $(\mathrm{OR}=4.8$; $95 \% \mathrm{Cl} 1.4$ - 16.6) remained predictors of students' preference for GrossAnatomy. The use of adequate lecture notes, relevant textbooks and use of audiovisuals in the course delivery is advocated for optimal performance. The learning of anatomy should be driven by an intrinsic interest, allowing students to use learning strategies that are more engaging and cognitive in nature.

Keywords: Anatomy Evaluation; Veterinary Education; Clinical Veterinary Students

\section{Introduction}

Anatomy education is often seen as a basic knowledge course that all in the

Vol. 14, No. 2 (2021). 1-13 
health field are required to take, thus it is at the center of the curricular debate in medical education (ElizondoOmana, R., Guzman-Lopez, S., Garcia-Rodriguez, M. (2005): Dissection as a teaching tool: past, present, and future. Anat Rec B New Anat 285 (1):11-15; Older J. Anatomy (2004): A must for teaching the next generation. Surg J R Coll Surg of Edinb Irel 2(2):79-90; McKeown, P., Heylings, D., Stevenson, M., McKelvey, K., Nixon, J., McCluskey, D. (2003): The impact of curricular change on medical students' knowledge of anatomy. Med Educ 37(11):954-961; Monkhouse, W. and Farrell, T. (1999): Tomorrow's doctors: today's mistakes? Clin Anat 12(2):131-134; Drake, R. (1998): Anatomy education in a changing medical curriculum. Anat $\operatorname{Rec} 253$ (1): 28-31). The debate goes on between educators who want it to remain a traditionally taught course and those who feel it should revolve around some of the more recent learning theories. Traditionalists fear that studentcentered curricula will shrink the importance and time spent on anatomical education (Elizondo-Omana, R., Guzman-Lopez, S., Garcia-Rodriguez, M. (2005): Dissection as a teaching tool: past, present, and future. Anat Rec B New Anat 285 (1):11-15; Older J. Anatomy (2004): A must for teaching the next generation. Surg J R Coll Surg of Edinb Irel 2(2):79-90; Monkhouse, W. and Farrell, T. (1999): Tomorrow's doctors: today's mistakes? Clin Anat 12(2):131-134). Opposing this view J. Vet. Anat. are those who think that studentcentered approaches must be adopted and that these student-centered approaches must play an integral part in anatomy education as it helps set the foundation for the rest of a student's medical education (Drake, $\mathrm{R}$. (1998): Anatomy education in a changing medical curriculum. Anat Rec 253(1):28-31; Terrell, M. (2006): Anatomy of learning: instructional design principles for the anatomical sciences. Anat Rec B New Anat 289(6):252-260; Morrone, A. and Tarr, T. (2005): Theoretical eclecticism in the college classroom. Inov Higher Educ 30:7-21; Miller, S., Perrotti, W., Silverthorn, D., Dalley. A., Rarey, K. (2002): From college to clinic: reasoning over memorization is key for understanding anatomy. Anat Rec 269(2):69-80; Percac, S. and Armstrong, E. (1998): Introducing a problem -based anatomy course in a traditional curriculum: a Croatian experience. Med Teacher 20:114-117). Student ideas about learning have been researched and classified by Saljo (Säljö, R. (1979): Learning in the learner's perspective. I. Some common-sense conceptions. Higher Education 8(4):443-451) and later added to by Marton, et al., (Marton, F., Dall'Alba, G., Beaty, E. (1993): Conceptions of learning. IJER. 19(3):277$300)$. The authors identified six major conceptions that students have about learning. These levels were placed in hierarchical order from simple ideas focused on factual information to Vol. 14, No. 2 (2021). 1-13 
complex ideas focused on deeper understanding and include: Increasing knowledge; Memorizing and reproducing; Applying; Under-standing; Seeing something in a different way; and Changing as a person. In order for anatomy classes to move towards student-centered instructional approaches, teachers must have a good sense of student ideas about learning anatomy and how this impacts on students' performance.

Veterinary Medical education program in Nigeria is for a total of six years or 12 semesters: one year or two semesters of pre-veterinary school (100 Level); three semesters of pre-clinical stage (200 and $1^{\text {st }}$ semester 300 Levels); three semesters of para-clinical stage $\left(2^{\text {nd }}\right.$ Semester 300 and $400 \mathrm{Lev}$ els) and four semesters of clinical stage (500 and 600 Levels). Admission into veterinary school at the University of Ibadan, Nigeria is either through preliminary entry (i.e. without prior undergraduate education) or direct entry into 200 level at the pre-clinical stage. Basic courses in Anatomy which include Gross anatomy, Microanatomy and Embryo-logy are taught at the preclinical stage of the veterinary education; while, clinical anatomy is taught at the clinical stage. The learning and passing of Anatomy as a subject at the pre-clinical stage is one of the pre-requisites to advance to the para-clinical stage, and this invariably aids learning of some clinical courses such as surgical clinics and meat inspection. The teaching of Veterinary Anatomy at the J. Vet. Anat.
University of Ibadan is akin to a student-centered instructional app-roach. Consequently, we set out to assess the performance and prefer-ence of para-clinical and clinical students, who have undergone the basic anatomy courses in their pre-clinical years, for the subject in relation to the students perceived idea about learning Veterinary Anatomy. This study aimed at determining the performance and preference of veterinary students about learning anatomy and their predictors.

\section{Methods}

\section{Study design and study population}

We conducted a pilot study among student populations in their para-clinical (400 level) and clinical (500 and 600 levels) stage of veterinary medical training at the Faculty of Veterinary Medicine, University of Ibadan, Ibadan, Nigeria.

\section{Questionnaire design and data col- lection}

A structured questionnaire containing 20 questions (Appendix I) was designed to determine the performance and the preference of veterinary students on learning anatomy and students' perceived ideas about learning anatomy that could predict their performance and preference for the subject. The pretested questionnaire was selfadministered to a total of 126 students comprising of thirty-nine $(73.6 \%$ of total class) 400 level students, fifty-two (86.7\% of total class) 500 level students and thirty-five $(42.2 \%$ of total

Vol. 14, No. 2 (2021). 1-13 
class) 600 level students. The students were randomly selected from a frame of students present after class lectures.

\section{Data analysis}

Data were imputed into Microsoft Excel 2007 and analyzed using Epi info ${ }^{\circledR}$ software version 3.5.4. Two outcome variables were considered i.e. passing anatomy at first sitting; and having preference for Gross-Anatomy over other anatomy courses. Descriptive statistics was done and statistically significant differences between the outcome variables and categorical independent variables such as students' demographics and perceived idea about influence of teaching aids, pattern of teaching Gross Anatomy, Microanatomy and Embryology, adequacy of continuous assessment, interest in anatomy and learning anatomy, lecturers' enthusiasm and the learning environment were determined by Fisher's exact test at $5 \%$ level of significance. Multivariable unconditional logistic regression was used to determine independent variables that could predict preference for GrossAnatomy as a course over Microanatomy and Embryology controlling for other covariates at $P<0.20$. Collinearity among predictors was assessed by the use of Chi square test for binomial variables. A manual backward selection method was used to select independent variables into the model. In the final models, only independent variables that were found to significantly J. Vet. Anat. affect the outcome at $\mathrm{P}<0.05$ were retained.

\section{Results}

Of the 126 respondents 67 (53.2\%) were male; while $87(69.1 \%)$ were in the clinical year. Ninety three out of the 126 respondents $(73.8 \%)$, reported the adequacy of continuous assessment and its positive contribution to improving knowledge of the Anatomy course. Less than half $(41.3 \%)$ of the respondents rated their love for anatomy compared to other pre-clinical courses as being very high. More so, less than half $(39.7 \%)$ of the respondents still remember and value the knowledge of Anatomy in surgery clinics or meat inspection. Most of them (73.0\%) passed all Anatomy courses at first sitting, and more than half $(54.8 \%)$ reported the use of their lecture notes as key to passing Anatomy. However, the use of combinations of lecture notes, textbooks and audiovisuals was highly significant $(\mathrm{OR}=20.2 ; 95 \% \mathrm{Cl} 2.4-$ 967.1) to passing Anatomy at first sitting when compared to the use of audiovisuals only. Other students' perceived ideas about learning anatomy were not significantly associated with passing anatomy at first sitting (Table 1). Most of the respondents $(87.3 \%)$ chose Gross-Anatomy as the most interesting of the three aspects of the Anatomy course and majority of these $(49.2 \%)$ attributed the choice to both the quality of teaching and the use of audiovisuals in the course delivery.
Vol. 14, No. 2 (2021). 1-13 
Independent variables such as the students' impression of systematic pattern of teaching Gross-Anatomy (OR = 3.8; $95 \%$ Cl 1.0 - 22.2); Impression about the pattern of teaching Microanatomy (OR $=0.2 ; 95 \% \mathrm{Cl} 0.04-0.8)$; Adequacy of continuous assessment (OR = 3.4; 95\% Cl 1.0 - 11.5); Impression about learning Anatomy $(\mathrm{OR}=$ $3.7 ; 95 \% \mathrm{Cl} 1.1-14.4$ ) and impression about the department (OR $=0.2 ; 95 \%$ $\mathrm{Cl} 0.1-0.8$ ) were significantly associated with the preference for GrossAnatomy to either Microanatomy or Embryology (Table 2). After adjusting for confounding independent variables, variables such as students' impression about learning Anatomy (OR $=5.3 ; 95 \% \mathrm{Cl} 1.4-19.5$ ); impression about the pattern of teaching Microanatomy $(\mathrm{OR}=0.1 ; 95 \% \mathrm{Cl} 0.02-0.4)$ and adequacy of continuous assessment (OR $=4.8 ; 95 \% \mathrm{Cl} 1.4-16.6)$ remained predictors of students' preference for Gross-Anatomy to either Microanatomy or Embryology in the logistic regression (Table 3 ).

\section{Discussion}

Student assessment is a dynamic and multi-faceted process with the aims being variable (Vergis, A. and Hardy, K. (2009): Principles of assessment: A primer for medical educators in the clinical years. Internet J Med Educ 1:15). Assessments are used principally to identify how much a student has acquired in terms of knowledge and learning skills (Anaf, Y. and Yamin, S.

J. Vet. Anat.
(2014): Difference and similarity of continuous assessment in Malaysian and Nigerian universities. J Edu Pract 2:73-82). Though assessment can be done through continuous assessment, final examination or a combination of both, the end goal is to impact on student learning (Rezigalla, A., Abdalla, A., Haider, S., Ali, Q., Alhassen, M. (2014): The impact of continuous assessment on the final results, a case study: College of Medicine, King Khalid University. Sudan Med Monit 9:149152). In this study, clinical and paraclinical students found continuous assessment as key to passing anatomy at first sitting when they were in preclinicals; this is an important feedback knowing that students typically detest taking continuous assessment tests and would rather have it cancelled or postponed.. The fact that anatomy involves factual memory of names could mean continually assessing the students, leads to better retention of memory and learning. Poljičanin, A., et al (2009): Daily mini quizzes as means for improving student performance in anatomy course. Croat Med J 50(1):55-60, reported that despite the frequency and possible associated stress, daily quizzes were associated with better academic success in the anatomy course in a Medical School. It is worrisome that less than $40 \%$ of students found their learning of Anatomy useful in clinical areas. This implies those students learnt anatomy basically to pass examinations and were not stimulated enough on clinical

Vol. 14, No. 2 (2021). 1-13 
implications of most of what they are learning. This may demand curriculum review or more practically a change in teaching strategies to emphasize clinical importance of anatomical details and this should be emphasized both in teaching and in assessments of the students. Though a high percentage of students passed veterinary anatomy at first sitting which reflects a lot on the quality of the students, it is important to know that they are being trained to be veterinarians and must be trained to embrace anatomy in regard to its application and not just what they have to know by rote to pass examinations.

A huge number of students chose Gross-Anatomy as their most interesting aspect of Anatomy relative to $\mathrm{Mi}$ croanatomy and Embryology. The factors for this as indicated by the students include quality of teaching and use of audiovisuals. It is thus important that teachers of veterinary anatomy have a sense of responsibility in communicating and ensuring learning by their students; the importance of audiovisual as key to preferring Gross Anatomy may not be divorced from quality of teaching. The absence of quality visualization of slides might have contributed to reduced preference for Microscopic Anatomy. At the department of Veterinary Anatomy, University of Ibadan, none of the lecturers do core research in embryology; this may in part be the reas very few students had keen interest in this aspect of anatomy. Overall, one cannot deny the fact that the students see and handle bones and museum specimen, and are all involved in dissection; these could have made the learning of Gross-Anatomy more interesting and easier. However, passion and quality of teaching by lecturers is also pivotal. According to Cake, M. (2006): Deep dissection: motivating students beyond rote learning in veterinary anatomy. J Vet Med Educ 33(2):266-271, the key to encouraging dissection for deep learning ("deep dissection") lies more in student motivation, personal engagement, curriculum structure, and "learning context" than in the nature of the learning activity itself.

\section{Conclusion}

Anatomy education is core to the foundation of veterinary medicine practice and cannot be over empha-sized. The use of adequate lecture notes, relevant textbooks and use of audiovisuals in the course delivery is advocated for optimal performance. More so, students' interest in other anatomy courses such as Micro-anatomy and Embryology can be improved through systematic delivery of the courses and administration of frequent continuous assessment tests. The learning of anatomy should be driven by an intrinsic interest, allowing students to use learning strategies that are more engaging and cognitive in nature, such as group discussions, writing reflections, designing and conducting experiments, and meta-cognition. 


\section{Acknowledgement}

The authors are grateful to Paraclinical and Clinical students of Veterinary Medicine, University of Ibadan, Ibadan, Nigeria for assisting with the questionnaire.

\section{References}

Anaf, Y. and Yamin, S. (2014): Difference and similarity of continuous assessment in Malaysian and Nigerian universities. J Edu Pract 2:73-82.

Cake, M. (2006): Deep dissection: motivating students beyond rote learning in veterinary anatomy. $J$ Vet Med Educ 33(2):266-271.

Drake, R. (1998): Anatomy education in a changing medical curriculum. Anat $\operatorname{Rec} 253(1): 28-31$.

Elizondo-Omana, R., GuzmanLopez, S., Garcia-Rodriguez, M. (2005): Dissection as a teaching tool: past, present, and future. Anat $\operatorname{Rec} B$ New Anat 285 (1):11-15.

Marton, F., Dall'Alba, G., Beaty, E. (1993): Conceptions of learning. IJER. 19(3):277-300.

McKeown, P., Heylings, D., Stevenson, M., McKelvey, K., Nixon, J., McCluskey, D. (2003): The impact of curricular change on medical students' knowledge of anatomy. Med Educ 37(11):954-961.

Miller, S., Perrotti, W., Silverthorn, D., Dalley. A., Rarey, K. (2002): From

J. Vet. Anat. college to clinic: reasoning over memorization is key for understanding anatomy. Anat Rec 269(2):69-80.

Monkhouse, W. and Farrell, T. (1999): Tomorrow's doctors: today's mis-takes? Clin Anat 12(2):131-134.

Morrone, A. and Tarr, T. (2005): Theoretical eclecticism in the college classroom. Inov Higher Educ 30:7-21.

Older J. Anatomy (2004): A must for teaching the next generation. Surg J R Coll Surg of Edinb Irel 2(2):79-90.

Percac, S. and Armstrong, E. (1998): Introducing a problem-based anatomy course in a traditional curriculum: a Croatian experience. Med Teacher 20:114-117.

Poljičanin, A., et al (2009): Daily mini quizzes as means for improving student performance in anatomy course. Croat Med J 50(1):55-60.

Rezigalla, A., Abdalla, A., Haider, S., Ali, Q., Alhassen, M. (2014): The impact of continuous assessment on the final results, a case study: College of Medicine, King Khalid University. Sudan Med Monit 9:149-152.

Säljö, R. (1979): Learning in the learner's perspective. I. Some commonsense conceptions. Higher Education 8(4): 443-451.

Terrell, M. (2006): Anatomy of learning: instructional design princi-ples for 
the anatomical sciences. Anat Rec B New Anat 289 (6):252-260.
Vergis, A. and Hardy, K. (2009): Principles of assessment: A primer for medical educators in the clinical years. Internet J Med Educ 1:1-5.

\section{Corresponding author: \\ Prof James O. Olopade \\ Department of Veterinary Anatomy \\ University of Ibadan \\ jkayodeolopade@yahoo.com}

Table (1): Univariate analysis of factors associated with passing all Anatomy courses at one sitting among para-clinical and clinical students at the Faculty of Veterinary medicine, University of Ibadan, Nigeria, 2015.

\begin{tabular}{|c|c|c|c|c|}
\hline Variables & $\begin{array}{c}\text { Passed all } \\
\text { Anatomy } \\
\text { courses at one } \\
\text { (1) sitting } \\
n=92(\%)\end{array}$ & $\begin{array}{c}\text { Passed all Anat- } \\
\text { omy courses at } \\
\text { more than one (1) } \\
\text { sitting } \\
n=34(\%)\end{array}$ & OR $(95 \% \mathrm{Cl})$ & $P$ value \\
\hline \multicolumn{5}{|l|}{ Gender } \\
\hline Male & $50(54.3)$ & $17(50.0)$ & $1.2(0.5 ; 2.8)$ & 0.81 \\
\hline Female & $42(45.7)$ & $17(50.0)$ & & \\
\hline \multicolumn{5}{|l|}{ Class of respondents } \\
\hline Para-clinical & $28(30.4)$ & $11(32.4)$ & $0.9(0.4 ; 2.4)$ & 1.00 \\
\hline Clinical & $64(69.6)$ & $23(67.6)$ & & \\
\hline \multicolumn{5}{|l|}{ Influence of teaching aids } \\
\hline None & $17(18.4)$ & $5(14.7)$ & Reference & \\
\hline Quality of teaching & $16(17.4)$ & $10(29.4)$ & $0.5(0.1 ; 1.7)$ & 0.39 \\
\hline Use of Audiovisuals & $11(12.0)$ & $5(14.7)$ & $0.7(0.1 ; 3.6)$ & 0.82 \\
\hline Contribution of both & 48 (52.2) & $14(41.2)$ & $1.0(0.3 ; 3.6)$ & 1.00 \\
\hline \multicolumn{5}{|c|}{$\begin{array}{l}\text { Impression about the pattern } \\
\text { of teaching Gross Anatomy }\end{array}$} \\
\hline Systematic & $40(43.5)$ & $15(44.1)$ & $1.0(0.4 ; 2.3)$ & 1.00 \\
\hline Non-systematic & $52(56.5)$ & 19 (55.9) & & \\
\hline \multicolumn{5}{|c|}{$\begin{array}{l}\text { Impression about the pattern } \\
\text { of teaching Micro Anatomy }\end{array}$} \\
\hline Systematic & $11(12.0)$ & $2(5.9)$ & $2.2(0.4 ; 21.2)$ & 0.52 \\
\hline Non-systematic & $81(88.0)$ & $32(94.1)$ & & \\
\hline \multicolumn{5}{|c|}{$\begin{array}{l}\text { Adequacy of Continuous As- } \\
\text { sessment }\end{array}$} \\
\hline Yes & $66(71.7)$ & $27(79.4)$ & $0.7(0.2 ; 1.8)$ & 0.52 \\
\hline J. Vet. Anat. & & 8 & Vol. 14 , No. 2 & 21). $1-13$ \\
\hline
\end{tabular}




\begin{tabular}{|c|c|c|c|c|}
\hline No & $26(28.3)$ & $7(20.6)$ & & \\
\hline \multicolumn{5}{|l|}{$\begin{array}{l}\text { Continuous assessment key } \\
\text { in passing Anatomy }\end{array}$} \\
\hline Yes & 68 (73.9) & $22(64.7)$ & $1.5(0.6 ; 3.9)$ & 0.42 \\
\hline No & $24(26.1)$ & $12(35.3)$ & & \\
\hline \multicolumn{5}{|l|}{ Teaching Aids key to passing } \\
\hline \multicolumn{5}{|l|}{ Anatomy } \\
\hline Audiovisuals & $11(12.0)$ & $14(41.2)$ & Reference & \\
\hline Lecture notes & $52(56.5)$ & $17(50.0)$ & $3.8(1.3 ; 11.4)$ & 0.01 \\
\hline Textbooks & $12(13.0)$ & $2(5.9)$ & $7.3(1.2 ; 80.1)$ & 0.02 \\
\hline Combination of $2 /$ more & $17(18.5)$ & $1(2.9)$ & $20.2(2.4 ; 967.1)$ & 0.001 \\
\hline \multicolumn{5}{|l|}{$\begin{array}{l}\text { Love for anatomy compared } \\
\text { to other pre-clinical courses }\end{array}$} \\
\hline Low/Dismal & $7(7.6)$ & $3(8.8)$ & Reference & \\
\hline Average & $48(52.2)$ & $16(47.1)$ & $1.3(0.2 ; 6.5)$ & 1.00 \\
\hline Very high & $37(40.2)$ & $15(44.1)$ & $1.0(0.2 ; 5.4)$ & 1.00 \\
\hline \multicolumn{5}{|l|}{$\begin{array}{l}\text { Knowledge of Anatomy valu- } \\
\text { able to surgery clinics and }\end{array}$} \\
\hline meat inspection & $40(43.5)$ & $10(29.4)$ & $1.8(0.7 ; 4.8)$ & 0.22 \\
\hline Very much & $52(56.5)$ & $24(70.6)$ & & \\
\hline \multicolumn{5}{|l|}{ Average/very little } \\
\hline \multirow{2}{*}{\multicolumn{5}{|c|}{$\begin{array}{l}\text { Impression about learning } \\
\text { Anatomy }\end{array}$}} \\
\hline & & & & \\
\hline Good understanding & $54(58.7)$ & $20(58.8)$ & $1.0(0.4 ; 2.4)$ & 1.00 \\
\hline Little/Poor understanding & $38(41.3)$ & $14(41.2)$ & & \\
\hline \multicolumn{5}{|l|}{$\begin{array}{l}\text { Impression about the Depart- } \\
\text { ment of Anatomy }\end{array}$} \\
\hline Well organized & $38(41.3)$ & $18(52.9)$ & $0.6(0.3 ; 1.5)$ & 0.34 \\
\hline Average/Poorly organized & $54(58.7)$ & $16(47.1)$ & & \\
\hline \multicolumn{5}{|l|}{$\begin{array}{l}\text { Impression about lecturers' } \\
\text { enthusiasm }\end{array}$} \\
\hline Above $70 \%$ score & $19(20.7)$ & $5(14.7)$ & $1.5(0.5 ; 5.6)$ & 0.64 \\
\hline Less than or equal $70 \%$ & 73 (79.3) & $29(85.3)$ & & \\
\hline \multicolumn{5}{|l|}{$\begin{array}{l}\text { Impression about technical } \\
\text { staff involved in teaching }\end{array}$} \\
\hline Excellent/Good & $56(60.9)$ & $19(55.9)$ & $1.2(0.5 ; 2.9)$ & 0.76 \\
\hline Average/ Below average & $36(39.1)$ & $15(44.1)$ & & \\
\hline
\end{tabular}


Table (2): Univariate analysis of factors associated with interest in Gross Anatomy above other Anatomy courses (Micro Anatomy \& Embryology) among para-clinical and clinical students at the Faculty of Veterinary medicine, University of Ibadan, Nigeria, 2015.

\begin{tabular}{|c|c|c|c|c|}
\hline Variables & $\begin{array}{l}\text { Interest in } \\
\text { Gross Anatomy } \\
\mathrm{n}=110(\%)\end{array}$ & $\begin{array}{l}\text { Interest in Micro } \\
\text { Anatomy \& Em- } \\
\text { bryology } \\
\mathrm{n}=16(\%)\end{array}$ & OR $(95 \% \mathrm{Cl})$ & $P$ value \\
\hline \multicolumn{5}{|l|}{ Gender } \\
\hline Male & $59(53.6)$ & $8(50.0)$ & $1.2(0.4 ; 3.8)$ & 0.99 \\
\hline Female & $51(46.4)$ & $8(50.0)$ & & \\
\hline \multicolumn{5}{|l|}{ Class of respondents } \\
\hline Para-clinical & 39 (35.5) & $0(0)$ & & \\
\hline Clinical & $71(64.5)$ & $16(100)$ & & \\
\hline \multicolumn{5}{|l|}{ Influence of teaching aids } \\
\hline None & $19(17.3)$ & $3(18.8)$ & Reference & \\
\hline Quality of teaching & $24(21.8)$ & $2(12.5)$ & $1.9(0.2 ; 24.5)$ & 0.84 \\
\hline Use of Audiovisuals & $10(9.1)$ & $6(37.5)$ & $0.3(0.04 ; 1.6)$ & 0.19 \\
\hline Contribution of both & $57(51.8)$ & $5(31.5)$ & $1.8(0.3 ; 10.2)$ & 0.70 \\
\hline \multicolumn{5}{|l|}{$\begin{array}{l}\text { Impression about the pattern } \\
\text { of teaching Gross Anatomy }\end{array}$} \\
\hline Systematic & $52(47.3)$ & $3(18.8)$ & $3.8(1.0 ; 22.2)$ & $0.05^{*}$ \\
\hline Non-systematic & $58(52.7)$ & $13(81.3)$ & & \\
\hline \multicolumn{5}{|l|}{$\begin{array}{l}\text { Impression about the pattern } \\
\text { of teaching Micro Anatomy }\end{array}$} \\
\hline Systematic & $8(7.3)$ & $5(31.3)$ & $0.2(0.04 ; 0.8)$ & $0.02^{*}$ \\
\hline Non-systematic & $102(92.7)$ & $11(68.7)$ & & \\
\hline \multicolumn{5}{|l|}{$\begin{array}{l}\text { Adequacy of Continuous As- } \\
\text { sessment }\end{array}$} \\
\hline Yes & $85(77.3)$ & $8(50.0)$ & $3.4(1.0 ; 11.5)$ & $0.05^{*}$ \\
\hline No & $25(22.7)$ & $8(50.0)$ & & \\
\hline \multicolumn{5}{|l|}{$\begin{array}{l}\text { Continuous assessment key } \\
\text { in passing Anatomy }\end{array}$} \\
\hline Yes & $76(69.1)$ & $14(87.5)$ & $0.3(0.03 ; 1.5)$ & 0.21 \\
\hline No & $34(30.9)$ & $2(32.5)$ & & \\
\hline \multicolumn{5}{|l|}{ Teaching Aids key to passing } \\
\hline \multicolumn{5}{|l|}{ Anatomy } \\
\hline Audiovisuals & 17 (15.5) & $1(6.3)$ & Reference & \\
\hline Lecture notes & $21(19.1)$ & $4(25.0)$ & $0.3(0.01 ; 3.6)$ & 0.58 \\
\hline Textbooks & $13(11.8)$ & $1(6.3)$ & $0.8(0.01 ; 64.6)$ & 1.00 \\
\hline Combination of $2 /$ more & $59(53.6)$ & $10(62.4)$ & $0.4(0.01 ; 2.8)$ & 0.57 \\
\hline \multicolumn{5}{|l|}{$\begin{array}{l}\text { Love for anatomy compared } \\
\text { to other pre-clinical courses }\end{array}$} \\
\hline Low/Dismal & $6(5.5)$ & $4(25.0)$ & Reference & \\
\hline Average & $56(50.9)$ & $8(50.0)$ & $4.5(0.8 ; 24.7)$ & 0.10 \\
\hline Very high & $48(43.6)$ & $4(25.0)$ & $7.6(1.1 ; 53.8)$ & 0.04 \\
\hline J. Vet. Anat. & & 0 & Vol. 14, No. 2 & 21). $1-13$ \\
\hline
\end{tabular}


Knowledge of Anatomy valuable to surgery clinics

Very much

Average/very little Impression about learning

Anatomy

Good understanding

Little/Poor understanding

Impression about the Department of Anatomy

Well organized

$45(40.9)$

65 (59.1)

5 (31.3)

$11(68.8)$

$69(62.7)$

41 (37.3)

5 (31.3)

11 (68.7)

Average/Poorly organized

Impression about lecturers'

enthusiasm

Above $70 \%$ score

Less than or equal $70 \%$

Impression about technical

staff involved in teaching

Excellent/Good

Average/ Below average

* Significant at $\mathrm{P} \leq 0.05$
$44(40.0)$

$66(60.0)$

$12(75.0)$

$4(25.0)$

22 (20.0)

$88(80.0)$

2 (12.5)

$14(87.5)$

$63(57.3)$

47 (42.7)

$12(75.0)$

$4(25.0)$

$1.5(0.5 ; 6.0)$

0.66

$3.7(1.1 ; 14.4)$

$0.04^{*}$

$0.2(0.05 ; 0.8) \quad 0.02^{*}$

$1.7(0.4 ; 16.9)$

0.74

$0.5(0.1 ; 1.6)$

0.28

Table (3): Unconditional Logistic Regression of factors associated with interest in Gross Anatomy above other Anatomy courses (Micro Anatomy \& Embryology) among para-clinical and clinical students at the Faculty of Veterinary medicine, University of Ibadan, Nigeria, 2015.

\begin{tabular}{|c|c|c|c|}
\hline Variables & OR & $95 \% \mathrm{Cl}$ & $\mathrm{P}$ value \\
\hline \multicolumn{4}{|c|}{ Impression about learning Anatomy } \\
\hline Good understanding & 5.3 & $1.4-19.5$ & 0.01 \\
\hline Little/Poor understanding & 1 (Reference) & & \\
\hline \multicolumn{4}{|c|}{$\begin{array}{l}\text { Impression about the pattern of teach- } \\
\text { ing Micro Anatomy }\end{array}$} \\
\hline Systematic & 0.1 & $0.02-0.4$ & 0.001 \\
\hline Non-systematic & 1 (Reference) & & \\
\hline \multicolumn{4}{|c|}{ Adequacy of Continuous Assessment } \\
\hline Yes & 4.8 & $1.4-16.6$ & 0.01 \\
\hline No & 1 (Reference) & & \\
\hline
\end{tabular}




\section{APPENDIX \\ Department of veterinary Anatomy, Faculty of Veterinary Medicine, University of Ibadan \\ NOTE: Before completing the Questionnaire, please take some time to read through the instructions that appear below:}

- $\quad$ Please read all the instruction carefully.

- $\quad$ All the information you provide will be kept strictly confidential.

- We are interested in your personal views, please do not discuss or compare answers with others and ensure that you give honest answers.

- $\quad$ Please $\operatorname{TICK}(\checkmark)$ where appropriate.

\section{SECTION A: DEMOGRAPHY}

1. Sex

2. Level of study
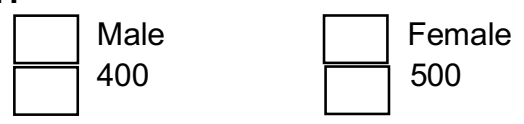
600

\section{SECTION B:}

1. Which was most interesting?

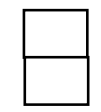

Gross Anatomy

Embryology

Microanatomy

2. What contributed to your choice in question 1 ?
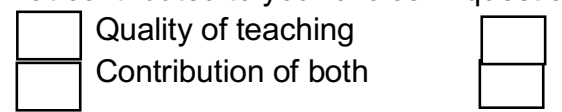

Use of audiovisuals None of these

Which do you find most interesting? (answer all 3)

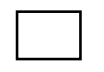
Gross Anatomy
$\square$ Practical
$\square$ None

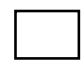
Micro Anatomy

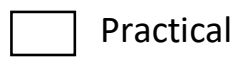
$\square$
None
$\square$ Embryology
$\square$ Practical
None

3. Has your choice above (Q3) increased your enthusiasm for further learning of Anatomy?
$\square$ Yes
$\square$ Not really
$\square$ I have no interest

4. What is your impression about the pattern of teaching Gross Anatomy?
$\square$ Systematic
$\square$ Just ok
$\square$ Haphazard

5. What is your impression about the pattern of teaching Micro Anatomy?
$\square$ Systematic
$\square$ Just ok
$\square$ Haphazard

6. What is your impression about the pattern of teaching Embryology?
$\square$ Systematic
Just ok
Haphazard

7. How will you rate the teaching of Clinical Anatomy? (600level only)

J. Vet. Anat. 
$\square$ Very high $\square$ Average $\square$ Low $\square$ Dismal

8. Continuous assessments were sufficient and added to my knowledge of Anatomy.
$\square$ Yes
$\square$ No
$\square$ NA

9. Continuous assessments were key in passing my final anatomy examinations.
$\square$ Yes
$\square$ No
$\square$ NA

10. Which of these was key to you passing Anatomy?

$\square$ My notes $\square$ Textbooks $\square$ Audiovisuals

11. Which of the following is your status?

passed all Anatomy courses at first sitting
failed one or two courses at first sitting
failed more than two courses at first sitting

12. Rate your love for anatomy compared to other Pre-clinical courses
$\square$ Very high

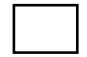
Average

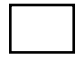
Low
Dismal

13. What is your own impression of you being an Anatomist?

$\square$ Very high $\square$ Will not be my first choice $\square$ Not for consideration

14. My knowledge of Anatomy is still remembered and valuable in surgery clinics and meat inspection.

$\square$ Very much $\square$ Very little Average

15. Which is your impression about learning Anatomy?

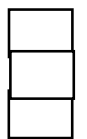

I understand it and I can apply it.

I understand a little though I passed

I have a poor knowledge of Anatomy

16. Which is your impression about the Department of Anatomy?

The department is well organized $\square$ Averagely organized
Poorly organized

17. Which is your impression at the enthusiasm of the lecturers to teaching Anatomy?

$\square$ I think over $70 \% \quad \square \quad \square 0 \%-70 \% \quad \square$ Below $50 \%$

18. What is your impression about the non-teaching staff that helped you while in Anatomy?

$\square$ Excellent $\square$ Good $\square$ Average $\square$ Below average

19. What was your best memory while learning Anatomy in Pre-clinicals? 